\title{
MARKET POLICY AND ENVIRONMENTAL POLICY: THE CASE OF THE CONSULTATION BOARD FOR THE ELECTION OF THE GOAL OF REDUCING THE CONTAMINATING LOAD DISCHARGE INTO THE MEDELLÍN RIVER DURING THE PERIOD 2006-2011*
}

Recibido: 10 de julio de 2014 • Aprobado 24 de agosto 2015

\author{
Alejandra García Cardona* \\ Juan Carlos Arango-Quintero**
}

\begin{abstract}
This article describes the agents participating in the process of implementing the remuneration rate due to the use of water, through negotiating the global goal of reducing the contaminating load, in the Metropolitan Area of Valle de Aburrá (2006-2011). The exploratory analysis based on the inductive method permitted analyzing a case study of implementing an instrument of contamination control in the given region. The study concludes that characteristics of each of the agents are decisive to participate in the political market of electing the global goal of reducing the contaminating load.
\end{abstract}

\section{KEY WORDS}

Remuneration rate, political market, environmental policy implementation process, symmetry in information

\section{JEL CLASSIFICATION}

Q57, Q58.

\section{CONTENT}

Introduction; 1. Method; 2. Results and discussion; 3. Conclusions; References

This article is the result of the research work "The political market in the rational choice of pollution for the preservation of water resources in the city of Medellin in the period 2006-2011- one explanatory approach". This research was conducted in the years 2007 and 2008 for the degree of Master in Economics, Universidad de Antioquia.

** Accountant, Universidad de Antioquia, Medellín, Colombia. Master in Economics, Universidad de Antioquia, Medellín, Colombia. Full-time profesor, Department of Public Accounting, Faculty of Economics and Administrative Sciences, Universidad de Medellin, Medellin, Colombia. Race $87 \mathrm{~N}^{\circ} 30-65$, Universidad de Medellín, Building 6 - 108, Medellín, Colombia. Email: agarcía@udem.edu.co.

*** Economist, Universidad de Antioquia, Medellín, Colombia. Master in Political Science, Universidad de Antioquia, Medellín, Colombia. Consultant, research and part-time professor, Universidad de Antioquia, Medellín, Colombia. 72-50 9th Street apt 412. E-mail: jcarango72@gmail.com. 


\section{POLIITICAS DE MERCADO Y POLÍTICAS AMBIENTALES: EL CASO DEL CONSEJO EN LA ELECCIÓN DEL OBJETIVO DE REDUCIR LA CARGA CONTAMINANTE VERTIDA EN EL RÍO MEDELLÍN EN EL PERÍODO 2006-2011}

\section{RESUMEN}

En este artículo se describen los agentes que participan en el proceso de aplicación de la tasa de remuneración por el uso del agua, mediante la negociación del objetivo mundial para reducir la carga contaminante en la Zona Metropolitana del Valle de Aburrá (2006-2011). El análisis exploratorio basado en el método inductivo permite realizar un estudio del caso de la aplicación de un instrumento de control de la contaminación en la región. El estudio llega a la conclusión de que las características de cada uno de los agentes son decisivas para participar en las políticas de mercado y elegir el objetivo mundial de reducir la carga contaminante.

PALABRAS CLAVE:

Tasa de remuneración, mercado político, implementación de la política ambiental, la simetría de la información.

JEL CLASSIFICATION

Q57, Q58.

\section{CONTENIDO}

Introducción; 1. Método; 2. Resultados y discusión; 3. Conclusiones; Bibliografía.

\section{POLÍTICAS DE MERCADO E POLÍTICAS AMBIENTAIS: O CASO DA CONSULTA PARA A ELEIÇÃO DO OBJETIVO DA REDUÇÃO DA CARGA CONTAMINANTE DESCARREGADOS NO RIO MEDELLÍN DURANTE O PERÍODO 2006-2011}

\section{RESUMO}

Este artigo descreve os agentes que participam do processo de implementação da taxa de remuneração devido à utilização da água, através da negociação a meta global de reduzir a carga contaminante, na Região Metropolitana de Valle de Aburrá (2006-2011). A análise exploratória com base no método indutivo permitido analisar um estudo de caso da implementação de um instrumento de controle de contaminação em uma determinada região. O estudo conclui que as características de cada um dos agentes são decisivas para participar no mercado político de eleger a meta global de reduzir a carga contaminante.

\section{PALAVRAS-CHAVE:}

Taxa de remuneração, mercado político, a política de ambiente processo de implementação, a simetria de informações.

\section{CLASSIFICAÇÃO JEL:}

Q57, Q58

\section{CONTEÚDO}

Introdução; 1. Método; 2. Resultados e discussão; 3. Conclusões; Referências 
Market and environmental policy: the case of the consultation board for the election of the goal of reducing the contaminating...

\section{INTRODUCTION}

The preservation of water resource is an essential economic problem of societies. The problem centers on the conflict between the almost unlimited demand made by individuals and companies of resources and the scarce supply of such resources. This unbalance originates a degradation of resources as a result of the actions of individuals in the market. Thus, their capacity to undertake rational and reasonable management of those resources will impact upon the preservation and prevention of damage generated by their use. In Colombia, in the specific case of the hydric resource, Legislation (art 63, 102 of the Constitution; art 82, 82,674 and 677 of the civil code; art 83 of the code of human resources) indicates that water is a public good or belonging to the Nation and only under exceptional instances it is treated as private property, subjected to the restrictions or limitations imposed by the administration for its use. Indeed, it has been its indiscriminate use what has generated the risk of depletion (Salamanca, 2001, p. 36).

The discrepancy between that which is possessed and that which is desired in terms of environmental quality is what gives rise to the environmental policy in a country (Field, 1998). This accounts for the legislation that establishes the type of interaction between the environment and man, and regulates their relationships. And the way man restricts or limits these relationships will impact upon the magnitude and the quality of services the environmental resources may offer man. Due to this, environmental policy is established to reach and maintain a desired level of quality of the environment. For this, governments from industrialized nations and governments from the Latin American nations have employed diverse elements: legal norms and dispositions, as well as economic instruments, which tend to improve and protect the environment. The enactment of said policy must answer to the rational selections tending to the efficient assignment of the natural resources.

Now, the origin of this norm -which includes the hydric resource- has several perspectives: 1) those posing the economic analysis ignoring the political processes that influence on the regulation (Laffont and Tirole, 1993; Romer and Rosenthal, 1987), processes that for Keohane, Revesz, and Stavins (1998) constitute the side of the supply of the regulation; 2) those examining the preferences of private industry for regulation and assume that the preferences of individuals prevail (Buchanan and Tullock, 1975), and 3) those considering a model of decisions, where resources can be assigned according to the pressures of interest groups competing for the assignation (Becker, 1983).

In Colombia, according to the Regulatory Commission on Potable Water and Basic Sanitation (CRA for its name in Spanish), regulation has been developed in 
three stages. The first took place between 1995 and 1997 based on positive economy criteria. The second, between 1997 and 1999, was frameworked within political economy criteria. And the third stage was conducted from 2000 to 2001 to comply with the legislation (Salamanca, 2001. pp. 141-142).

As one of its environmental policies, Colombia implemented the economic instrument of remuneration rate. This is governed by the basic principle that those contaminating water must pay for the contamination they cause to this natural resource in the nation. The instrument is geared to modifying the contaminating behaviors through the incorporation, in the economic activity, of the environmental and social costs of the damage caused and of the costs of recovery of the resource. Besides, the nation adopted the remuneration rate with charges for contamination based on the formulations by Baumol/Oates -efficiency and equity of environmental quality; in spite of not obtaining the economic optimum or correcting on a total basis the problem of externality-, seeking to advance on decontamination through agreed upon measures to control dumping (Mancera and Ávila, 2004).

Regarding the application of the rate, such generates revenue that should be destined to preventing, mitigating, compensating, and solving the damage caused or paying for the use of the resources. Nonetheless, the Regional Autonomous Corporations are in charge of managing these resources as free destination revenue, which generates the incentive for them to maintain or increase the collection, rather than discouraging the inadequate use of the resource, given that, according to article 46 of legislation 99 of 1993, the income generated by the rates are revenue belonging to the regional and urban environmental authorities.

In Colombia, two hydric quality parameters were regulated to charge for the remuneration rate: the biochemical oxygen demand (BOD) and the total suspended solids (TSS). However, in Decree 1594 of 1984 another 30 contaminants were considered, but none of these has been regulated (Mancera and Ávila, 2004). This has impeded the application of the rate to the emissions of chemical contaminants from industrial activity, which are considered the principal cause of water contamination in the nation.

In spite of the aforementioned, the mechanism of the rate for use of water seeks to improve the supply of the hydric resource by stimulating rational use and funding of the management and administration of the resource and its waterways in each of the basins, to permit its preservation, regulation, and arrangement. Although some of the Regional Environmental Corporations are aware of this mechanism, they have not had an effective management to make it operative, which has not 
Market and environmental policy: the case of the consultation board for the election of the goal of reducing the contaminating...

permitted them to generate greater incorporation of users, or require the legalization of connections by illegal users.

Additionally, the Corporations that have implemented the rate mechanism do not have clear control and follow up mechanisms that permit updating the data on property owners assigned waterways, nor do they verify that the amount granted is the amount used. This implies serious deficiencies in the base records that hinder a charge of the real consumed value.

According to Mancera and Ávila Zabala (2004) some of these Corporations have found that goals of decontamination are not reached in the respective jurisdiction, in the main because the information on the levels of BOD and TSS "was not substantiated by clear and real information", nor were the estimations on the potential contamination reduction capacity of the hydrographic basins.

The consequence of everything stated above is that the regional factor has gradual increasement semester after semester. Among others, this is related to the low frequency of control and follows up by environmental authorities, the lack of waste water treatment systems in the municipalities, besides political negligence in the rate implementation process.

Also, the Constitution of 1991 strengthened the Colombian environmental policy. That was done via the concept of sustainable development that enabled environmental and potable water sanitation to be addressed in the nation as public utilities in the hands of the State. Likewise, it assigned the government with functions like the protection of environmental diversity and integrity, promotion of environmental education, imposition of legal sanctions for damages caused to the environment, among others. The ulterior legislative development gave a judicial order to institutionalism in the environmental setting.

Legislation 99 of 1993 empowered the Ministry of the Environment to manage and preserve the renewable natural resources. Also, the norm granted the regional environmental authorities ${ }^{1}$ the faculty to exert the environmental functions of evaluation, control and follow up of water use, in the area of its jurisdiction. Additionally, the regulation suggested that whosoever discharges contaminants without exceeding some pre-established limits must pay a remuneration rate.

1 Legislation 99 created the National Environmental System — SINA for its name in Spanish — which has the Ministry of the Environment as governing body, 33 regional autonomous and sustainable development corporations who manage the resources, 4 environmental administrative departments, 5 Research Institutes as technical and scientific support, a Special Administrative Unit of the National Natural Parks System, the departments, municipalities and districts. 
The regulation of the remuneration rate functions, in effect, from Decree 901 of 1997. On one part, the norm regulates, among others, elements like: generating event (direct and indirect use of water as receptor of point discharges), minimum tariffs, regional factors, active and passive subjects, mechanisms of collection and monitoring and control. In addition, upon fixing the rates, the Decree considers criteria like: the goal of reducing the contaminating load, recognition of regional diversity; availability, cost of opportunity, and capacity of resource assimilation, and the socioeconomic conditions of the population affected.

Decree 3100 of 2003 repeals the previous. Although it maintains much of Decree 901, it adds a relevant matter on the establishment of the goal of reducing the contaminating load. Goal established through a consultation process, whose formal start will be through an administrative act of the regional environmental authorities.

In Valle de Aburrá, the consultation process for the establishment of the goal of reducing the contaminating load ${ }^{2}$ by point discharges onto the Medellín River (2006-2011), was regulated by the environmental authority, Metropolitan Area of Valle de Aburrá (AMVA), with resolution 000563 of 13 October 2004. The process of implementing the remuneration rate in the Medellín River basin started with the same resolution. Then, the Environmental Authority modified the process with resolution 000175 of March 24, 2006.

Although the analysis of the Keohane, Revensz, and Stavins (1998) model describes the different approaches - from each of the agents and their interaction in the political market - on the motives of the implementation of the norm to solve the deficiencies of the anthropogenic interventions in natural resources. Such is circumscribed to the space of perfect competition between supply and demand and only poses the possible scenarios of imperfect competition without delving into its logic and possible dynamics.

In this sense, the case analysis herein presented not only describes the imperfections of the specific political market, but advances in an approach that tries to explain the substantial of the imperfections. For this, each of the players from the

2 The establishment of the global goal of reducing the contaminating load applied in Colombia was regulated only for two substances subject to charge or hydric quality parameters related to charging the remuneration rate: biochemical oxygen demand (BOD) and total suspended solids (TSS). (Resolution 0273 of 1997 from the Ministry of the Environment); although Decree 1594 of 1984 considers another 30 contaminants, of which none has been regulated. This has hindered the application of the rate of emissions of chemical contaminants from industrial activity, which are considered the principal cause of water contamination in the nation. 
Market and environmental policy: the case of the consultation board for the election of the goal of reducing the contaminating...

political market of the selection of the Global Reduction Goal was described. This qualifies the legitimate power conferred to the Metropolitan Area of Valle de Aburrá to profile it as the supply agent of the negotiation; while fine tuning the relevance of the contamination discharged by each direct user of the Medellín River, to justify to the regulated community as the demand parties of the market under analysis.

\section{METHOD}

Stemming from inductive method of qualitative research, the political scenario created for selection of the global goal of reducing the contaminating load is studied, during the 2006-2011 period, to decontaminate the hydrographic basin of Valle de Aburrá. The exploratory analysis presents a case study, the real experience of implementing an environmental policy in a given region.

For the aforementioned, the documentary evaluation of 15 proceedings elaborated during the meetings between the negotiators of the global goal of reducing the contaminating load, permitted identifying the agents who participated in the consultation board. Thereafter, these were interviewed on the consultation process. After conducting the interviews, these were transcribed. Then, the traditional supply and demand model and elements of microeconomic theory facilitated the description of the behavior of each of the players based on the information from the proceedings and the information from the interviews.

\section{RESULTS AND DISCUSSION}

The results allude to the characterization of the two agents of the political market (supply and demand) within the context of the Consultation board. In the first place, it is introduced the traits of the supply, in this instance the AMVA; in the second place, it is shown that the corresponding to the demand (polluters of the Medellín River), represented by the regulated community.

\subsection{The supplier}

The AMVA, based on its jurisdiction, delineated the product and established its target demand. For such, it proceeded through three steps: 1) identification of the agents of the regulated community and the respective jurisdiction with respect to the Medellín River; 2) the selection of said community and the definition of the guidelines to convoke it to the negotiation given the jurisdiction; and 3) the design of the product denominated global goal of reducing the contaminating load (MGRCC for its name in Spanish). Hereinafter, details of each will be offered. 


\subsubsection{Identification of the agents of the regulated community and of the respective jurisdiction}

The AMVA is the competent environmental authority to establish the supply of the goals of reducing the contaminating loads of the two components discharged in sections two and three of the Medellín River and its tributaries, the Biochemical Oxygen Demand (BOD5) and the Total Suspended Solids (TSS). Both sections imply the exercise of authority of said entity like identification of demanding parties settled in the concrete geographic portion. To divide the river into sections with the corresponding area covered, the environmental authority considered three aspects: the amount of information provided by the agents who discharge in the section (self declarations), the water quality, and works to be conducted.

The first section ( $\mathrm{Tl}$ ) comprises a rural sector in the jurisdiction of the Regional Autonomous Corporation of Central Antioquia - CORANTIOQUIA ${ }^{3}$ —; the second encompasses the urban area among the cities of Caldas, La Estrella, Sabaneta, Itagüí, Medellín, and Bello; and the third includes the municipalities of Copacabana, Girardota, and Barbosa. Given that the last two sections were jurisdiction of AMVA, a decision was taken on these regarding the objective goal of specific loads; hence, section one was not subject to decision. Also, AMVA considered three criteria: the amount of information provided by the agents discharging in the section (self declarations), water quality and infrastructure work to be conducted. Sections two (T2) and three (T3), will not only permit the exercise of the environmental authority upon the players who contaminate, but they will also facilitate identifying them given that they were settled in the concrete geographic portion. Additionally, said division, as suggested by AMVA (2006), was "an adequate manner of showing results joined to actions and having the user in mind" (p. 5). This is fundamental when suppliers segment their market goal under geographic criteria. And most of all when a political player exerting power over another to guarantee diminished contamination of a public good like the Medellín River.

Upon identifying the respective jurisdiction, the AMVA - as competent environmental authority - established the offer from the corresponding global goal of reducing the contaminating load according to the two components discharged in

3 Legislation 99 of 1993 which instituted in Colombia the Ministry of the Environment and reorganized the public sector for management and preservation of such and its renewable natural resources set the articulation of a National Environmental System. This system integrates territorial environmental authorities or autonomous corporations (CAR), the Colombian National System of Protected Areas (SINAP for its name in Spanish) and the Regional System of Protected Areas (SIRAP for its name in Spanish). The Regional Autonomous Corporation of Central Antioquia (CORANTIOQUIA) is one of the 26 corporations in existence. Its jurisdiction comprises 80 municipalities from central Antioquia and it is inhabited by 3,200,000 individuals. 
Market and environmental policy: the case of the consultation board for the election of the goal of reducing the contaminating...

T2 and T3 of the Medellín River and its tributaries: the biochemical oxygen demand $\left(\mathrm{BOD}_{5}\right)$ and the total suspended solids (TSS). Given its jurisdiction, the environmental authority decided on the objective goal of reducing specific loads in both sections (Table 1). This decision implied user participation of the river in the definition of the regulating instrument under the form of the information provided with respect to its levels of contamination loads.

Table 1. Target load discharge with reduction year 2011 in Tons/year

\begin{tabular}{|l|l|r|r|}
\hline Parameter & Sector & Section 2 & Section 3 \\
\hline \multirow{5}{*}{ BOD5 } & EPM - Significant Industrial Sector & $12,870.10$ & 1442.19 \\
& EPM - Domestic Sector & $38,937.85$ & 1184.44 \\
& Individual - Sector Goal (EPM Subtotal) & $51,807.95$ & 2626.63 \\
& Sector Goal - Load users not connected to & 1299.04 & 1321.93 \\
& EPM & $53,106.99$ & 3948.56 \\
\hline \multirow{5}{*}{ TSS } & Global Goal - Total Load & 3656.30 & 50.04 \\
& EPM - Significant Industrial Sector & $28,603.17$ & 816.30 \\
& EPM - Domestic Sector & $32,259.47$ & 866.34 \\
& Individual - Sector Goal (EPM Subtotal) & 1792.01 & 1183.82 \\
& Sector Goal - Load users not connected to & $34,051.48$ & 2050.16 \\
\hline
\end{tabular}

Source: AMVA (2006)

\subsubsection{Selection of the demand and criteria for its call given the jurisdiction}

The AMVA selected the demand through a call to sectors generating discharges of waste waters. Those invited were the public service provider company, connected and unconnected industries ${ }^{4}$. Likewise, the invitation was also extended to control organisms like the National Prosecutor's Office (Procuraduría General de la Nación), the Comptroller of the city of Medellín, and the municipal legal representations, as well as the mayors of the municipalities from the jurisdiction area, representatives from the academic sector and some environmental NGOs. Given the technical nature of the environmental issue, the AMVA concern revolved around qualifying the information offered to each of the players invited.

\footnotetext{
$4 \quad$ Names of companies from the industrial sector will be mentioned in the section of demand characterization.
} 
The AMVA tried to solve the problem of information asymmetry on the remuneration rate and its operation by segmenting the distinct agents. The procedure was carried out through meetings with each of them to make them aware and then attract them to the consultation board. Once this was accomplished, more qualified participation was possible from the different protagonists from the political market in selecting the MGRCC.

\subsubsection{The product design}

Speaking of a market implies mentioning a product. In the specific case of the consultation board, the product to be negotiated among the agents from the political market was the remuneration rate and its gradual implementation through the MGRCC. The MGRCC is characterized for being a product composed of the sum of the individual and sector goals. Each corresponds to a demand or user of the hydric resource. What is interesting about the product is that it implied the commitment of the demand players to reduce during one year the $\mathrm{BOD}_{5}$ and TSS discharges in the respective section and in a determined percentage. This depended upon whether the users discharged or not onto the sewage system of Empresas Públicas de Medellín (EPM).

For the product offered in the market to be in effect that demanded there must be a need to satisfy. In this study case, to create the need for the MGRCC, it was fundamental for the AMVA to consider a normative reference. For this, both agents, supplier and demand players, parted from an "initial reference framework or ZERO STATE, against which the goals of reducing future load must be negotiated and which will serve as reference to establish the tendencies of the contaminating phenomenon under discussion" (AMVA, 2006, p. 5) (upper case letters are from the original). The zero state alludes to the river conditions before the negotiation; additionally, it determines - during a given moment - which are the loads discharged onto the body of water, identifies who discharges them, and its recovery capacity in the contaminated section.

The aforementioned implied the existence of a "Base Line of Contamination by Liquid Discharges" (AMVA, 2006, p. 5). Said line justified the MGRCC; additionally, it described the state and availability of the resource based on the characterization of the discharges and on the self declarations by demanding parties on their semester and/or loads per year. In all, the process of creating the need for the product contained three steps: 1) identification of amounts of $\mathrm{BOD}_{5}$ and TSS discharged by the river users in the respective section; 2) aggregation of the loads in each section; and 3) five-year projection of the loads from each demanding party according to variation indexes in the discharges. 
Market and environmental policy: the case of the consultation board for the election of the goal of reducing the contaminating...

Besides the MGRCC, the supplier provided two more products to control waste waters and decontaminate the hydric resource, such as: regulating and facilitating instruments. The first, of two types: economic like the remuneration rate, and command and control. Both are obligatory for all users contaminating the river. The latter, the facilitators, voluntary agreements or covenants the demand parties put into operation to reduce contamination and rational use of the available water. The regulating instruments, given their legal nature, are binding for those involved; thereby, requiring negotiation. This is not the case with facilitating instruments because their object is the sectorial and entrepreneurial competitiveness and not compliance with a policy, despite its link with an environmental policy.

\subsection{The demand parties}

Based on segmentation, two groups emerged from the regulated community: the sewage system provider entities with a load over $20 \%$ discharged onto the water source and other users of the hydric resource.

The following are specific features of both.

\subsubsection{Entity in charge of providing public sewage system services in Valle de Aburrá}

One of the most important demand parties in the political market of the MGRCC Consultation board was EPM. This entity's importance lied in that it managed more than $80 \%$ of the discharge generated by the population in the Metropolitan Area of Medellín. The figure is nothing more than the reflection of an entrepreneurial history dating over 100 years, marked by three significant events (EPM, 2005): 1) the organization of the sewage service as an economic activity in 1888; 2) transferring the service from private parties to the municipality in 1955;3) the normative changes of 1994. This last aspect implied two important issues. First, the new conception of the household sewage public service ${ }^{5}$; and second, the character acquired by the service provider, which due to norm requirements had to be a State-run commercial or industrial company or shareholder societies.

Specifically, fee of the remuneration rate remains if the goals of decontamination are reached, otherwise the regional factor is increased and thus the rate to be paid for the fee. In other words, the regional factor determines pollution reduction in order to achieve the preset level of decontamination.

Defined by legislation 142 of 1994 (art. 14, numeral 23) as: "the municipal collection of wastes, mainly liquids, through pipelines and conduits". The legislation also applies to complementary activities: transport, treatment, and final disposal of wastes. 
Because of this, EPM has managed for over 50 years the transport, treatment, and final disposal of $\mathrm{BOD}_{5}$ and TSS discharges. This turned the Entity into the largest cause of contamination of the Medellín River, given that it is responsible for point source discharges. Consequently, because of the company's economic activity, it does not perceive the river as a hydric resource, but as a channel where it deposits the discharges (Osorio, 2008). The main reason for this perspective lies in the costs that would be implied for users of the sewage system to have a healthy resource. In this regard, Osorio (2008) states: "[we must ask] society at large what type of river it wants to see how much it is willing to invest, how much it is willing to pay. Then, if there were a different context of degree of development, degree of revenue, standard of living it is possible to have a better view of the quality of the river" (sic). According to the affirmation, it is necessary to say that maintaining the quality of a natural resource depends upon the community's willingness on a large basis to pay, which is determined by the level of awareness of its citizens.

Considering the river as a simple dump implied that EPM demanded from AMVA an individual goal of reducing the contaminating load (MIRCC for the term in Spanish). The MIRCC worked for the Company as a way of "limiting the coercive power" (Stigler, 1971, p. 4) ${ }^{6}$ of the environmental authority. In keeping to the Colombian normative framework, EPM complied with that strict required by the "Colombian legal disposition to guarantee quality of the river" (Osorio, 2008), and kept it to the permitted level of regulated substances. Had it been possible to carry out other activities for sanitation of the resource, without doubt, the Entity would have done so, as long as it did not affect on a significant basis its costs.

The important role performed by EPM justified its presence in the Consultation Board. The administration of $92 \%$ of the discharges (AMVA, 2006, p. 40) given the development of the economic activity complementary to that of sewage, led to the "(...) express citation of the environmental authority, in this instance the Metropolitan Area" (Osorio, 2008). Thus, EPM consolidated the nature of large user of the river, naming two representatives to answer the AMVA call.

\subsubsection{Other users of the hydric resource}

The other users of the hydric resource - second division of the regulated community established by the norm and because of such second demand party of the legislative product - had two characteristics. First, the regulated community attended the Roundtable in response to the call from the environmental authority, and in representation of the industries located along the Metropolitan Area of Valle de Aburrá.

$6 \quad$ It is the term used by Economic Regulation Theory to justify the demand for environmental regulation. 
Market and environmental policy: the case of the consultation board for the election of the goal of reducing the contaminating...

Second, it was a sector not connected to the EPM sewage network, and by virtue of this, it constituted less than $10 \%$ of the direct discharge onto the Medellín River.

Let us have a detailed look at both features.

\subsubsection{Location and representation of the agents in the market}

The representatives from the industrial sector considered that the fact of being or not connected to the EPM network was not a strong argument to conceive the river as a hydric resource, given that they continued to consider it as a dump site for the sub-products of their economic activity. Given that the sectorial goal of reducing the contaminating load (MSRCC for the term in Spanish) was applicable to users subjected to paying the remuneration rate, the companies had to commit to said goal. The commitment implied internalizing the contamination in production costs, with the usual effect that these could increase. At this precise moment when non-compliance with the reduction of discharges by a user would affect all the companies located along the banks of the Medellín River. This was because the MSRCC applied to the whole business sector, which could have an adverse affect on the sectorial interests.

To sum up, the value of the return rate will be kept only if the goals are achieved. In case the goals are not achieved the regional factor will increase which will in turn increase the cost regarding the rate. In other words, the regional factor is the one that determines the reduction in contamination until reaching the prestablished level to reach the goal.

Given the aforementioned, the industrialists consolidated their interests in the Board expressed in a posture agglutinated around the river issue. They saw the hydric resource from the regional as a whole. However, the environmental authority conceived it in fractioned manner, and so sought to discuss it during the consultation instance, in spite of the noise this generated during the negotiation of the goal. Upon considering it in fragmented manner, the factories located to the south of Medellín, near the San Fernando treatment plant, would suggest that the EPM Sanitation Plan implied in fact decontamination by them. While companies from the north would argue unequal conditions, given that they did not have a sewage plan ${ }^{7}$ (Giraldo, 2008). In all, the speakers for the industrialists sat at the Board in representation of a sector not differentiated in terms of the location by sections.

\footnotetext{
7 Given the geographic location, the discharge of waste water from companies could be classified from north to south of Valle de Aburrá into three groups: a) those from the south discharged into the sewage system and then treated at the San Fernando Plant; b) those from the center-north gathered by the EPM system, but with expectation of treatment in the future Plant in Bello; c) those discharged or not discharged onto the EPM sewage system, but located after the future Plant in Bello.
} 
The previous alludes to the solidarity of the connected industrial parties with not connected, regarding discharges (AMVA, 2006, p. 4). Solidarity perceived in the sense of sharing among them the responsibility for the contamination. This is covered by the norm, given that "the Political Constitution carries a concurrent duty from the State and from individuals, to protect the natural resources. It may not be said that it is an exclusive obligation of the State because [each individual] is also responsible for the preservation of the natural resources (...). Then, under that perspective, when saying that solidarity exists, meaning a concurrence in the obligation of the State and the individual, of the authority, of the provider and of the user; all fit therein." (Osorio, 2008) (Italics included by the authors). In other words, the role of the sector in the sanitation of the hydric resource was conceived as something that complements, from its responsibility in principle and effect, all the other social players.

Regarding the representation of the industrialists in the consultation board, three important arguments coexist: representativeness, participation, and experience. The following delves into these elements.

The first alludes to the ANDI participation in the scenario of the political market, speaking in representation of a conglomerate of sectors and trade groups at the national setting. In other words, "within their primary quality as speakers for the interests of private enterprise, the ANDI assumes the representation of its affiliates with national and foreign entities dealing with economic, judicial, social, environmental issues and other entrepreneurial matters" (ANDI, 2008); turning representation into a factor that confers preponderance to the trade group, within the different players on the Board.

The second argument, representation of users not interconnected to the EPM network alludes to direct participation in the Consultation Board by four of the companies from Valle de Aburrá: Enka de Colombia S.A., Papelsa S.A., Conquímica, and Fabricato-Tejicóndor; all of which AMVA, according to Giraldo (2008), convoked because they "had a greater load." However, the Proposal document, reproduced by the representatives, mentions some specifics that could help to understand the presence of the participants. For example, Textiles Fabricato-Tejicóndor, on the moment of negotiation, had invested an unspecified sum in the document, in the separation of sewage and in the construction of collectors to communicate them to those owned by EPM. The Papelsa S.A. property line coincided with the terrain ending sector three of the Medellín River. That is, in this company was where the AMVA river jurisdiction ended (Berger et al., 2006, p. 11).

The third argument is the experience of the companies in the environmental area, which permitted the same degree of information about the issue of discharges and, hence, about the remuneration rates. The generation of this symmetry of information 
Market and environmental policy: the case of the consultation board for the election of the goal of reducing the contaminating...

resulted in flawless communication among negotiators participating on the Board. In this regard, speakers for industry from the south and center (ANDI) of Valle de Aburrá convene in their appreciations. Restrepo (2008) states that "Conquímica S.A. affiliated to the South Aburrá Chamber of Commerce, arrived to the Consultation Board by express invitation from the director of said Chamber, in echo of AMVA; given the Company's experience in environmental themes". Also, Giraldo (2008) holds that "AMVA knows where there are industries people (sic) [trained to have] the level of interlocution and [continuity of such]." Giraldo (2008) also associates said characteristic to the size of the company and to the discharges it generates.

\subsubsection{Representativeness of agents in the market}

Related to the second and last feature of the sector not connected, there is the event generating the remuneration rate. That is, it is a sector that is legitimated as a demand party of the goal in the Consultation Board by generating direct discharges onto the hydric resource of the Metropolitan Area. This agent, as a company that provides public services, aggregates the industrial and domestic sectors. In terms of contamination, they contribute $4.9 \%$ of $\mathrm{BOD}_{5}$ and $7.2 \% \mathrm{TSS}$, concerning the industrial sector, while the residential participated with $2.1 \%$ of $\mathrm{BOD}_{5}$ and $2.3 \%$ TSS (Berger et al., 2006, p. 8). Additionally, this was a sector not connected that included 25,000 households from the municipality of Caldas to that of Barbosa, a minimum amount compared to 3-million inhabitants in Valle de Aburrá (Cardona, 2008; AMVA, 2006).

Because over $90 \%$ of the discharge from Valle de Aburrá is managed by the entity providing the sewage public service in the zone, and in keeping with its economic activity, legislation authorized it to transfer to its clients the value of the remuneration rate for the waste waters. Instead, the other users of the resource are direct generators of the event that originates the rate: they discharge punctually, for which they must show reductions of the load received by the hydric resource. If this were not so, they would have an increase factor in said rate, which would make conditions different for this sector; given that it implied an increase in costs for each of the users (Osorio, 2008)

This could be summarized in that the other users discharged onto the Medellín River, for which they bore the direct value of the political instrument. Discharges that in terms of contamination do not imply high loads, but in terms of that taxed, lead to great efforts from each of the companies involved with the event generating the Remuneration Rate. The plausible explanation is that the companies belonging to this group had to commit to implementing cleaner production systems to comply with an MSRCC, or because the sector did not comply with such and; consequently, 
it was subject to its increased value. In both cases, decontamination or contamination, the cost was internalized with the consequences that were already mentioned.

In general terms, the motives leading to the second division of the regulated community to require the MSRCC product in the Consultation board were: the distribution of the sector not connected in sections two and three; the ANDI representative quality as a trade group; the participation of four companies - two with particular characteristics - ; their experience in the environmental setting; and the representativeness of the contamination discharged onto the hydric resource. The goal applying to the industrial and domestic part disconnected from the EPM sewage system.

It is worth noting that in the Consultation board "two proposals were introduced, one by Empresas Públicas de Medellin, and another by industrialists participating in the Consultation board" (AMVA, 2006, p. 6). Hence, there were two products required by the respective agents in this political market of the MGRCC consultation: a legislative product denominated MIRCC and another also normative product called MSRCC.

Figure 1. Schematic diagram of the representation of the demand parties in the Consultation Board

Usuarios de la red de alcantarillado de EE. PP. MM.

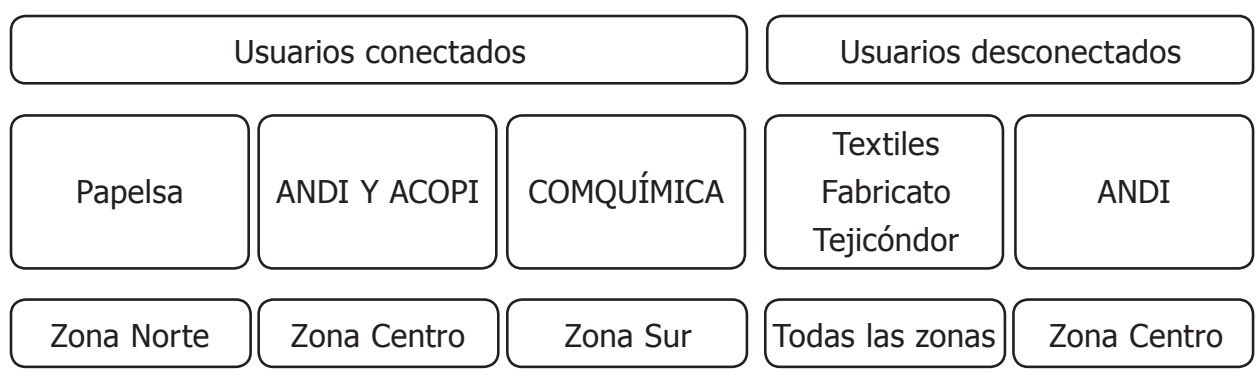

Source: Authors' elaboration based on Berger et al (2006)

Figure 1. The Consultation board was attended by industries connected and not connected to the EPM sewage network. EPM represented the first. The latter had delegates from specific companies like Enka de Colombia S.A., Papelsa S.A., Conquímica, and Fabricato-Tejicondor. Simultaneously, the trade groups were backed by the Colombian National Association of Entrepreneurs (ANDI for its name in Spanish) and the Colombian Association of Micro, Small, and Medium Companies (ACOPI for its name in Spanish), who represented industries and companies connected and not connected. 
Market and environmental policy: the case of the consultation board for the election of the goal of reducing the contaminating...

\section{CONCLUSIONS}

Each of the agents intervening in the decision of the goals of reducing the contaminating loads on the hydrographic basin of Valle de Aburrá have specific characteristics, which are decisive to participate in the political market of the selection of such goals. On one side, there is the supplier AMVA, who legitimates its environmental authority functions and creates the need for the legislative product on the demand parties by identifying them and convoking them to the Consultation board; given the assignment of the demand to the Entity jurisdiction. Also, there are two demand parties: the company transporting, treating, and disposing of wastewater from Valle de Aburra and the rest of the users of the resource. The first is responsible for the greatest part of the direct discharges onto the hydric resource during the development of the public service; the second demand party gathers all the industry from the Metropolitan Area, those not connected to the city's sewage system in particular. Consequently, the AMVA regulated community, in the furtherance of its respective economic activities, attends the Board because of two fundamental reasons: the concomitant traits they have for the supplier, regarding the complementary nature of the discharges perceived by the Medellín River; and to solve for the Authority the asymmetry of the information it has on the contamination dumped onto the river.

For the 2012-2016 period, a new negotiation board will be convoked with the contaminating agents. Therefore, it is proposed to study this new consultation process of the global goal of reducing the contaminating load for the 2012-2016 period of which it would be expected greater enforceability in decontaminating the Medellín River.

\section{REFERENCES}

AMVA - Área Metropolitana del Valle de Aburrá - (2006). Subdirección Ambiental. Proceso de Implementación de Tasas Retributivas. Acta No. 4. Medellín, 8p.

AMVA - Área Metropolitana del Valle de Aburrá - (2006). Acta No. 13. Proceso de Implementación de Tasas Retributivas. Medellín, 7p.

AMVA - Área Metropolitana del Valle de Aburrá - (2006). Acta No. 14. Proceso de Implementación de Tasas Retributivas. Medellín, 8p.

ANDI - Asociación Nacional de Empresarios de Colombia - (2008). Naturaleza y Estructura.

Becker, Gary S (1983). A Theory of Competition Among Pressure Groups for Political Influence. In: The Quarterly Journal of Economics, Vol. 98, August, p. 371-400.

Berger F., Juan A. Et al. (2006). Proceso de Consulta para la Fijación de Metas de Reducción de Carga Contaminante por Vertimientos Puntuales Al Río Medellín de Acuerdo con las Reso- 
luciones 563 del 13 de octubre de 2004 y 175 del 24 de abril 2006 del Área Metropolitana Del Valle de Aburrá. Propuesta de Metas. 42p.

Buchanan, James M. and Tullock, Gordon (1975). Polluters' Profits and Political Response: Direct Controls Versus Taxes. In: The American Economic Review. Vol. 65, March, p. 139-147. Cardona, Margarita (2008). Ingeniera Ambiental del Área Metropolitana del Valle de Aburrá. AMVA. Interview conducted 7 April 2008.

EPM- Empresas Públicas de Medellín- (2005). Historia Institucional. Empresas Públicas de Medellín.

Field, Barry C. (1998) Economía Ambiental, una introducción. Primera edición, Santa Fé de Bogotá: Mc Graw Hill. 587 p.

Giraldo, M. (2008). Zootecnista. Representante de la ANDI ante la Mesa de Consulta de la Meta Global de Reducción de la Carga Contaminante. Interview conducted 12 March 2008.

Keohane, N.O., R. Revesz, and R.N. Stavins (1998). The Choice of Regulatory Instruments in Environmental Policy. In: Harvard Environmental Law Review Vol. 22, p. 313-67.

Laffont, J. y Tirole, J. (1993). A theory of Incentives in Procurement and Regulation. Cambridge, Massachussetts: MIT Press.

Mancera Rodríguez, Néstor Javier y Ávila Zabala, Mónica. (2004). Las tasas ambientales: instrumentos poderosos y aplicación débil. In Revista Economía Colombiana. No 301, p. 76-83.

Osorio S., Álvaro. (2008). Abogado Subidrector Jurídica Energía. Empresas Públicas de Medellín -ESP-. Interview conducted 3 March 2008.

Restrepo Silva, Lucas. (2008). Chemical engineer and Technical Director at Conquímica S.A. Telephone conversation 16 April 2008.

Romer, Thomas and Howard Rosenthal. (1987). Moderm Political Economy and the Study of Regulation. In: Public Regulation: New Perspectives on Institutions and Policies, ed Elizabeth E. Bailey, p. 73-116. Combridge: MITPress.

Stigler, G. (1971). The Theory of Economic Regulation. In: Bell Journal of Economics and Management Sciences. Vol. 2, p. 3-21. 